\title{
Alfred Marshall versus The Historical School?
}

\author{
Geoffrey M. Hodgson
}

Abstract: A false account of Marshall's engagements with the historical school is found among modern commentators. This false account involves the central proposition that Marshall was an opponent of the historical school. This false account has survived and prospered because it has fitted into more general conceptions of intellectual history, held by both orthodox and heterodox economists. To many orthodox economists, Marshall was a hero who greatly contributed to the development of neoclassical economic theory, and fought valiantly against the 'atheoretical' historicists. Likewise, to many heterodox economists, Marshall was a villain who greatly contributed to the development of neoclassical economic theory, and machinated against the 'more realistic' historicists. Such statements are difficult to reconcile with the fact that Marshall repeatedly referred positively to the ideas of the German historical school. It is argued in this paper that Marshall’s opposition to the historical school was confined to its anti-theoretical wing, principally William Cunningham. In other important respects Marshall’s position was compatible with German and British historicism.

\section{Structured Abstract:}

\begin{tabular}{|l|l|l|}
\hline Purpose of this paper & $\begin{array}{l}\text { What are the reason(s) } \\
\text { for writing the paper or } \\
\text { the aims of the } \\
\text { research? }\end{array}$ & $\begin{array}{l}\text { This paper counters the view that Alfred Marshall } \\
\text { was an opponent of the historical school. This } \\
\text { false account has survived and prospered } \\
\text { because it has fitted into more general } \\
\text { conceptions of intellectual history, held by } \\
\text { both orthodox and heterodox economists. }\end{array}$ \\
\hline $\begin{array}{l}\text { Design/methodology/a } \\
\text { pproach }\end{array}$ & $\begin{array}{l}\text { How are the objectives } \\
\text { to be achieved? Include } \\
\text { the main method(s) used } \\
\text { for the research. What is } \\
\text { the approach to the topic } \\
\text { and what is the } \\
\text { theoretical or subject }\end{array}$ & $\begin{array}{l}\text { Marshall's affinity with the historical school is } \\
\text { established by examining his writings and his } \\
\text { relationship with historical school sympathisers in } \\
\text { Britain. }\end{array}$ \\
\hline
\end{tabular}




\begin{tabular}{|l|l|l|} 
& scope of the paper? & \\
\hline Findings & $\begin{array}{l}\text { What was found in the } \\
\text { course of the work? This } \\
\text { will refer to analysis, } \\
\text { discussion, or results. }\end{array}$ & $\begin{array}{l}\text { It is established that Marshall regarded his work as } \\
\text { building on historical school insights, and he } \\
\text { repeatedly referred positively to the ideas of } \\
\text { the German historical school. It is argued in } \\
\text { this paper that Marshall's opposition to the } \\
\text { historical school was confined to its anti- } \\
\text { theoretical wing, principally William } \\
\text { Cunningham. In other important respects } \\
\text { Marshall's position was compatible with }\end{array}$ \\
\hline $\begin{array}{l}\text { What is original/value } \\
\text { of paper }\end{array}$ & $\begin{array}{l}\text { What is new in the } \\
\text { paper? State the value of } \\
\text { the paper and to whom. }\end{array}$ & $\begin{array}{l}\text { In preceding literature, Marshall's affinities with } \\
\text { the historical school have been denied, } \\
\text { unacknowledged, or unexplored. }\end{array}$ \\
\hline
\end{tabular}

Keywords: Alfred Marshall, Historical School

Classification: Conceptual paper

This essay explains why Alfred Marshall has been misunderstood in some modern accounts of his relationship with the historical school. ${ }^{[1]}$ These misunderstandings are so pervasive that a false account of Marshall's engagements with the historical school has emerged and spread among modern commentators. This false account involves the central proposition that Marshall was an opponent of the historical school. For instance, Robert Skidelsky (1983, p. 43) stated that Marshall 'rejected the main contentions of the German historical school'.

Such statements are difficult to reconcile with the fact that Marshall in several places referred positively to members of the German historical school, in his Principles and elsewhere. In his 1979-81 lectures at the LSE, Lionel Robbins (1998, p. 306) attempted to explain away these little known positive comments. Robbins did so on the unsupported and implausible grounds that Marshall 'was in some sense terrified' of the German historicists. However, the only instance that Robbins could cite of a disagreement between Marshall and 
any historicist was his altercation in Cambridge with William Cunningham. Furthermore, Robbins neglected to point out that in his debates with Cunningham, Marshall willingly accepted a core proposition of the historical school case and acknowledged the problem of historical specificity. This problem starts from the presumption that different socio-economic phenomena may require theories that are in some respects different from each other (Hodgson, 2001). Robbins blindly ignored the fact that Marshall (1949, p. 31) had openly declared in his Principles that 'new ... economic doctrines' were required in different historical periods. On this issue, Cunningham and Marshall were on the same side, and Robbins on the other. By ignoring this central question and some further evidence discussed below, Robbins managed to rewrite history and infer that Marshall was an antagonist of the historical school.

This false account has survived and prospered because it has fitted into more general conceptions of intellectual history, held by both orthodox and heterodox economists. To many orthodox economists, Marshall was a hero who greatly contributed to the development of neoclassical economic theory, and fought valiantly against the 'atheoretical' historicists at Cambridge. Likewise, to many heterodox economists, Marshall was a villain who greatly contributed to the development of neoclassical economic theory, and machinated against the 'more realistic' historicists at Cambridge. The false account fits the prejudices on both sides.

However, this account does not stand up to minimal critical scrutiny. It is a fact that Marshall openly and repeatedly praised and supported many of the ideas and leaders of the German historical school. Furthermore, he understood and addressed the problem of historical specificity in his writings. In other words, Marshall openly acknowledged that some economic systems in history might require some specific theories or principles to explain them that would not then apply to all economies. 
As for the supporters of the historical school in Cambridge, the argument here is that that they were at least partly responsible for their own marginalisation. This was especially the case with Cunningham, who took an untenable methodological and theoretical position and alienated himself even from other historicist sympathisers. Herbert Foxwell - the other leading historicist in Cambridge - also does not fit into the standard account. Foxwell was Marshall's close friend and ally until 1908, when Marshall's decision not to back Foxwell as his successor for the Cambridge chair in economics forced them irrevocably apart.

This 1908 incident reflects upon Marshall's character. Again, he was far from the unprincipled schemer and operator that he has sometimes been depicted. True, he could be selfish, tactless, tiresome, obstinate, vain and humourless. ${ }^{[2]}$ However, when he failed to support his closest friend Foxwell, it was not due to duplicity but on the grounds of his own honestly declared academic judgment. His verdict had some foundation. In about 1906 Marshall had developed serious and ostensibly warranted reservations about Foxwell's academic discernment and his capabilities as a teacher. Furthermore, in 1908, Foxwell's record of academic publications was much inferior to that of the successful candidate for the Cambridge chair.

Some accounts of the period have highlighted the policy disputes of the time, particularly over the issue of free trade. Gerard Koot (1987) for example, in an otherwise useful overview, brought policy controversies over free trade to the fore. For Koot, the 'mercantilism' of the historical school took precedence over their methodology. However, there is neither a necessary nor a logical connection between the methodological standpoints of the historical school and any opposition to free trade. It is true that Marshall supported free trade and that several German historicists were critical of such a policy. Cunningham and Foxwell opposed Marshall on this question. But such policy controversies in Britain were 
hardly a direct 'clash of methods' of the substance, tone and deep methodological impact of the great Continental battle between Carl Menger and Gustav Schmoller.

Not only have Marshall's relationships with the historical school been misunderstood; Marshall's times also have been misunderstood. It has become a commonplace to refer to the 1870s as the decade of 'the marginal revolution' in economic thought. Yet the more careful historians of ideas have shown clearly that it was less of a sudden revolution than an intermittent process, traceable back to the writings of a variety of economists working as early as the 1830s (Black et al., 1973; Howey, 1960; Ekelund and Hébert, 2002). Furthermore, its impact was delayed. Prior to 1890, most of the published general histories of economic thought failed to mention the term 'marginal utility'. No written account of this supposed 'marginal revolution’ in ideas appeared until well into the twentieth century.

For any informed economist working in the years from 1883 to 1914, the AustroGerman Methodenstreit was as recognisable and important an event as the latterly so-called 'marginal revolution'. Indeed, in retrospect, the deep methodological issues raised in this celebrated 'clash of methods' are even more momentous than the theoretical shift, pioneered by the marginalists, from cost-based to utility-based theories of price. ${ }^{[3]}$

\section{It's all in Marshall: His respect for the German historical school}

Marshall was one of the acknowledged pioneers of marginal utility theory. But it is important to note that this did neither place him in a close alliance with Carl Menger, nor make him an enemy of the German historicists. Marshall was fluent in German. Like many aspiring young economists in the nineteenth century, he went to Germany to study under the tutelage of members of the historical school. He was in Dresden in 1868 and in Berlin in 1870-71. He came into contact with several German economists, including Wilhelm Roscher. 
In contrast to modern dismissals, references to the German historical school throughout Marshall's writings are respectful and positive, rather than scornful or dismissive. ${ }^{[4]}$ Emphatically, Marshall absorbed rather than rejected much of the doctrine of the German historical school (Hammond, 1991; Hutchison, 1998). Even in the later editions of his Principles, Marshall (1949, p. 634) retained a highly laudatory view of the German historicists:

It would be difficult to overrate the value of the work which they and their fellowworkers in other countries have done in tracing and explaining the history of economic habits and institutions. It is one of the great achievements of our age ...

Accordingly, Marshall was not in general opposition to the historical school. On the contrary, he often praised their achievements. Furthermore, despite his controversies with some British historicists, during his lifetime Marshall was not depicted as a general opponent of historicism. $^{[5]}$

Nevertheless, Marshall's economic thought was more individualistic and utilitarian than that of most German historicists. Many historical school economists had argued against the utilitarian view that human welfare could be equated with the satisfaction of subjective desires. However, even on this point, Marshall's position was characteristically conciliatory. On the one hand, in his Principles, he described wealth as 'desirable things ... which satisfy wants.' But on the other hand he admitted 'those elements of the wealth of a nation which are commonly ignored when estimating the wealth of the individuals composing it', including some of the 'non-material elements' stressed by 'German economists' (Marshall, 1949, pp. 45, 49). Marshall's utilitarianism, like Spencer's, was not purely individualist or subjective. If happiness was conceived as the ultimate end, Marshall was just as interested in the concrete conditions under which happiness could prosper. Furthermore, Marshall was also influenced by the metaphor of the social organism, favoured by both Spencer and the German historical 
school. This also qualified his individualistic outlook. Marshall (1949, pp. 20-21) wrote, in Spencerian terms, that 'economists, like all other students of social science, are concerned with individuals chiefly as members of the social organism. ... [The] life of society is something more than the sum of the lives of its individual members.'

It is useful to compare the methodological attitudes of Marshall and Menger, especially in relation to the older historical school. Like Menger, Marshall understood the limits of the inductive method. They both agreed that economics cannot proceed from facts alone. They also agreed that economics cannot avoid making use of some universal principles. Their methodologies both focused primarily on the individual, rather than the system. But there was a significant difference of emphasis. Marshall's individualistic viewpoint was highly qualified. Having made the given, rational individual the universal foundation of economic theory, Marshall $(1949$, pp. 76, 631) then went on to qualify this in his Principles. He wrote of 'new activities giving rise to new wants', noting that human character 'is a product of circumstances' and acknowledging that 'changes in human nature' can be significant and rapid.

Most strikingly, in contrast to Menger, Marshall did not reject the problem of historical specificity: unlike Menger he saw it as a legitimate and important question for economists. Crucially, Marshall acknowledged the principle of historical specificity in his inaugural lecture as Professor of Political Economy at Cambridge. This event was two years after Menger's attack in the Untersuchungen. Every informed economist was aware of Menger's controversial challenge to Germanic orthodoxy. Significantly, Marshall did not side with the anti-historicist counter-revolution. In his lecture, taking a historicist view, Marshall criticised the English economists of the early nineteenth century because 'they did not see how liable to change are the habits and institutions of industry' (Marshall, 1885, p. 155). Writing as if he were a card-carrying historicist, Marshall (p. 154) further noted that: 
the mathematico-physical group of sciences ... have this point in common, that their subject-matter is constant and unchanged in all countries and in all ages. ... [But in contrast] if the subject-matter of a science passes through different stages of development, the laws which apply to one stage will seldom apply without modification to others; the laws of science must have a development corresponding to that of the things of which they treat.

This is an unambiguous recognition of the problem of historical specificity. In this passage Marshall recognises, like the German historicists, that 'laws which apply to one stage' of economic development 'will seldom apply without modification to others'. Likewise, in his Principles - the first edition of which appeared in 1890 - Marshall (1949, pp. 30-31) acknowledged that: 'Though economic analysis and general reasoning are of wide application ... every change in social conditions is likely to require a new development of economic doctrines.'

Consider the venom that many economists since the 1930s have directed against the German historical school. Compare Marshall's contrasting sympathy for the ideas and achievements of the historicists.Today, anyone with historicist sympathies on the scale of Marshall's would probably be barred even from a junior university post in any leading department of economics.

Nevertheless, despite his outstanding achievements, detailed problems remained in Marshall's methodological position. He did not elaborate nor explain how the 'laws which apply to one stage' should be modified and applied to another. He did not show what degree or type of modification he had in mind. To what extent, and in what manner, would economic theory have to change to be applied to a changed economic reality? No answer to this question was apparent. Marshall's statements, while acceptable to many in the historical school, could be interpreted either in terms of mere parametric adjustment of an universal 
theory, or that quite different laws would pertain from one historical period to another. Marshall fully acknowledged the problem of historical specificity but he did not make a sustained attempt to resolve it. Instead he concentrated on the formulation of the seemingly universal Principles, for which he became famous.

\section{Greedy for facts: But not by facts alone}

Philosophically, Marshall was an admirer of Immanuel Kant. From a similar perspective, Marshall recognised the limitations of all empirical enquiry. Kant (1929, p. 41) had argued in 1781 that 'though all our knowledge begins with experience, it does not follow that it all arises out of experience.' Accordingly, without dismissing empirical work, Marshall (1885, p. 171) recognised the need for additional, theoretical endeavour:

Greedy then as the economist must be for facts, he must not be content with mere facts. Boundless as must be his gratitude to the great thinkers of the historic school, he must be suspicious of any direct light that the past is said to throw on the problems of the present.

For Marshall, historical facts were essential, but they cannot on their own provide us with the answers (Marshall, 1949, p. 32). Thus at once he paid unbounded tribute to the work of the historical school, but simultaneously undermined the naive empiricist views in their midst. The naïve belief that facts alone were enough to derive universal principles was characteristic of the older historical school. But after the Methodenstreit many of the historicists took a more sophisticated view. Marshall was not attacking the historical school as a whole but the its surviving empiricist wing. Marshall (1885, p. 166) explained in his inaugural lecture that the mere observation of sequences of events explained nothing:

facts by themselves are silent. Observation discovers nothing directly of the actions of causes, but only of sequences in time. ... In economic or social problems no event has 
ever been the exact precedent of another. The conditions of human life are so various: every event is the complex result of so many causes, so closely interwoven that the past can never throw a simple and direct light on the future.

Not only are facts unable to speak for themselves, but also the method of inductive inference is confounded by the complexity of economic phenomena. However, while showing that economics could not rely on induction alone, Marshall appealed to the authority of a leading and sophisticated member of the German historical school. In his Principles, Marshall (1949, p. 24) quoted and endorsed Schmoller's statement that: 'Induction and deduction are both needed for scientific thought as the left foot and the right foot are both needed for walking., ${ }^{[6]}$

Accordingly, Marshall tried to appeal to both sides in the induction versus deduction debate. Although he accepted deduction, he was quite cautious in introducing deductive arguments based on universal assumptions. The deductive core was to be confined to such universal forces as supply and demand. In his inaugural lecture Marshall (1885, pp. 158-9) saw the central and universal core of economic theory as

a machinery to aid us in reasoning about those motives of human action which are measurable. ... But, while attributing this high and transcendent universality to the central scheme of economic reasoning, we may not assign any universality to economic dogmas. ... It is not a body of concrete truth, but an engine for the discovery of concrete truth ...

In his Principles, he outlined a similar idea. Appealing appropriately to biology, Marshall (1949, p. vii) suggested that amidst the historical or evolutionary variety found in economic and biotic phenomena, common features and principles might exist:

As, in spite of the great differences in form between birds and quadrupeds, there is one Fundamental Idea running through all their frames, so the general theory of the 
equilibrium of demand and supply is a Fundamental idea running through the frames of all the various parts of the central problem of Distribution and Exchange.

For Marshall, some general principles were appropriate, corresponding to the elements that were common to diverse phenomena. He argued that the 'general theory of the equilibrium of demand and supply' formed an essential element of the deductive engine of economic theory. However, he wished to restrain and complement this engine’s powers. For instance, Marshall (1949, p. 638) warned that the function of analysis and deduction in economics is not to forge a few long chains of reasoning, but to forge rightly many short chains and single connecting links. ... as surely as every deduction must rest on the basis of inductions, so surely does every inductive process involve and include analysis and deduction.

As a result, deduction had to be restrained and limited by empirical anchors. On the other hand, Marshall argued that the danger in some work of the historical school was that, in placing an impossible faith in facts alone, they were inattentive to their own acts of classification and logic; and they ignored their own use of deductive reasoning.

When therefore it is said that a certain event in history teaches us this or that, an element of deductive reasoning is introduced, which is more likely to be fallacious the more persistently it is ignored. For the argument selects a few out of the group of conditions which were present when the event happened, and tacitly, if not unconsciously, assumes that the rest are irrelevant. The assumption may be justifiable: but it often turns out to be otherwise. (Marshall, 1885, p. 166)

As a result

the most reckless and treacherous of all theorists is he who professes to let facts and figures speak for themselves, who keeps in the background the part he has played, 
perhaps unconsciously, in selecting and grouping them, and in suggesting the argument (Marshall, 1885, p. 168).

Here Marshall turned the argument against the naïve empiricists. By claiming that truth is based on the facts alone, they had concealed the prior and unavoidable task of theory in selecting, understanding and arranging those facts. Empiricism was thus a 'treacherous' doctrine, because it downplayed the necessary role of the theorist and the comparison of different theoretical approaches. Those that claimed to build science on facts alone, deluded themselves and others into the false belief that theoretical preconceptions are avoidable. On this issue, Marshall, like Menger, was on strong philosophical ground. Empiricism is flawed as an epistemology, and induction alone is weak as a method.

Overall, Marshall tried to steer an intermediate position between deductivism and empiricism. Although his philosophical position was underdeveloped, his intuitions were consistent and strong. He was highly sceptical of naïve empiricism, on the one hand, and of excessive deductivism and formalism, on the other. As further evidence of this we can cite an interesting correspondence between him and William A. S. Hewins, a man of historicist sympathies who was the first Director of the London School of Economics. Marshall wrote to Hewins on 12 October 1899, concerning the economics curriculum at the School:

The fact is I am the dull mean man, who holds Economics to be an organic whole, and has little respect for pure theory (otherwise than as a branch of mathematics or the science of numbers), as for that crude collection and interpretation of facts without the aid of high analysis which sometimes claims to be part of economic history. (Whitaker, 1996, vol. 2, p. 256)

Clearly, Marshall was trying to steer a middle course between overly mathematical economic theory and banal empiricism. Marshall again wrote to Hewins on 29 May 1900: 
Much of 'pure theory' seems to me to be elegant toying: I habitually describe my own pure theory of international trade as a 'toy'. I understand economic science to be the application of powerful analytical methods to unravelling the actions of economic and social causes, to assigning each its part, to tracing mutual interactions and modifications; and above all to laying bare the hidden causas causantes. (Whitaker, 1996, vol. 2, p. 280)

Along very similar lines, Marshall wrote to Francis Edgeworth on 28 August 1902:

In my view 'Theory' is essential. ... But I conceive no more calamitous notion than that abstract, or general, or 'theoretical' economics was economics 'proper.' It seems to me an essential but a very small part of economics proper: and by itself sometimes even - well, not a very good occupation of time. (Pigou, 1925, p. 437; Whitaker, 1996, vol. 2, p. 393)

Sadly, a century later, the economics profession as a whole, including Marshall's own Faculty of Economics at the University of Cambridge, has become much preoccupied with the 'elegant toying' that Marshall had looked down upon so critically. The study of real causes within socio-economic systems, that Marshall saw as the essence of economic science, has become much less fashionable today than the exhibition of mathematical technique for its own sake.

True to his Kantian affections, Marshall saw the priority of such a theory over empirical enquiry. Rightly recognising the limitations of empiricism, he searched for an overarching conceptual framework within which he could build his theoretical system. He thought that he had found the answer in the 'synthetic philosophy' of Herbert Spencer. Marshall thus followed Schmoller and others in importing ideas from Spencerian biology and philosophy into economics (Pribram, 1983, p. 217). 
Even in biology, in the second half of the nineteenth century, Spencer rivalled Charles Darwin in standing. Trained in physics and mathematics, and being a brilliant polymath and synthesiser, Spencer made a significant contribution to biology and extended evolutionary ideas to ethics and social science. Spencer's unified system of ideas was popular and engaging. It seemed that the natural and social sciences could be unified on the basis of a few universal principles. Spencer too offered the lure of a general theory.

Marshall read his works avidly, incorporating several Spencerian notions into his economics (Hodgson, 1993; Thomas, 1991). As Peter Groenewegen (1995, p. 167) has remarked: 'The significant influence of Spencer on Marshall's thinking cannot be repeated too often'. Spencer provided the key theoretical, or rather meta-theoretical, framework upon which Marshall attempted to build. It was thus a great tragedy for Marshall that Spencer's influence began to wane rapidly in the early years of the twentieth century (Hodgson, 1993).

John Neville Keynes was an early pupil and devotee of Marshall. Keynes’s Scope and Method of Political Economy (1891) was largely an attempt to develop Marshall's methodology, particularly by trying to steer between induction and deduction, and between description and formalism. Marshall read the proofs of the book and was quite positive about them, although he urged that more attention should be given to contemporary German economists (Moggridge, 1997, pp. 355-6). In his book, Keynes attempted to combine induction with deduction, arguing (p. 227) that economics 'must both begin with observation and end with observation'. Observation to establish premises, deduction to reach conclusions, observation once more to verify them. This work also claimed a continuity of doctrine between the Marshallians at Cambridge and what had gone before. The text minimised theoretical confrontation and tried to find the best in all points of view. Accordingly, it failed to resolve many of the outstanding questions of methodological controversy. 


\section{The Methodendiskurs: Marshall and the British historicists}

Some members of the historical school in Britian were as misled by an empiricist epistemology as were their earlier co-thinkers in Germany. ${ }^{[7]}$ Marshall countered them on this issue, promoting an ostensibly balanced position, with a role for both induction and deduction. He was careful to cite the authority of Schmoller on this point, and he recognised the value of the empirical work of the historical school.

But even Marshall's balanced statements went too far for Cunningham. Cunningham had studied briefly in Germany, in Tübingen in 1868 and Mannheim in 1874. He became a scholar at Trinity College in 1869 and was taught by Marshall. From 1878, Cunningham taught and examined history at Cambridge, and was appointed a University Lecturer in that subject in 1884. He was an applicant to the Cambridge chair to which Marshall was appointed in December 1884. To evade Marshall's departmental authority, he resigned his university lectureship in 1888 to take up a fellowship at Trinity College. From 1891 to 1897, Cunningham was also Tooke Professor of Economics at King’s College, London. ${ }^{[8]}$ He was an occasional teacher at the London School of Economics, from its foundation in 1895. In 1906 he resigned his Trinity Fellowship. He was ordained in 1873 and was vicar at Great St. Mary’s church in Cambridge from 1887 until 1908, when he became Archdeacon of Ely. However, he still continued to give occasional lectures in Cambridge and London.

Foxwell, another Cambridge historicist, was one of Marshall's first pupils. He was elected a fellow of St. John's College, Cambridge in 1868. In 1881 he succeeded Jevons as professor of political economy at University College London, while retaining his fellowship at St. John's. Until 1908 he was a very close friend of Marshall. Foxwell favoured the emphasis on demand in the writings of Malthus and Jevons, over the focus on costs of production in the works of Ricardo and Marx. Foxwell thus prefigured J. M. Keynes's stress on 'effective demand' (Koot, 1987, ch. 6). In 1901 Foxwell emphasised that 'in the economic region, all 
practical questions should be determined on their merits, after detailed and historical investigation of the particular circumstances, and not by summary reference to maxims or dogmas supposed to be of universal application. ${ }^{[9]}$

Nevertheless, this was not so far from the view of Marshall, and the two sometimes expressed their closeness on such matters. In their correspondence of 1897 on matters of method, Foxwell suggested to Marshall that J. N. Keynes’s position was midway between that of Marshall and his own. Marshall (Whitaker, 1996, vol. 2, p. 179) responded in conciliatory tone to Foxwell on 30 January 1897: 'Most of the suggestions which I made on the proofs of Keynes's Scope and Method were aimed at bringing it more into harmony with the views of Schmoller.' Marshall thus emphasised his methodological affinities with a leading member of the younger German historical school. Although Marshall admitted differences of methodological emphasis with Foxwell, he did not make much of them.

Overall, Foxwell was more sympathetic to deductive economic theory than Cunningham. In particular, Foxwell had been a friend of Jevons and was an admirer of his work. Foxwell (1919, p. 387-8) later documented that Cunningham’s 'general depreciation of economic theory' had enticed 'friendly controversy' from Foxwell himself, as well as from other Cambridge colleagues. Although, in this obituary of Cunningham, Foxwell also admitted that he had found himself 'more and more inclined to move in his direction.' Foxwell’s doctrinal breach with Marshall had slowly widened. In the late 1890s Marshall criticised the overly descriptive content of Foxwell's teaching. After 1903, Foxwell joined Cunningham in arguing for more study of historical subjects on the Cambridge Economics Tripos.

In contrast, Cunningham had entered the doctrinal battle much earlier and with much greater force, after he had lost against Marshall in the 1884 competition for the Cambridge chair. Like his predecessors in the German historical school, Cunningham (1885) defended 
the focus on national economic units and aggregates. However, he aligned himself with the extreme empiricist wing of the historical school, thereby to become one of Marshall's foremost antagonists (Maloney, 1985, pp. 99-105). Cunningham resolutely opposed the view, expressed convincingly by Marshall in his inaugural lecture, that theory could not be built on facts alone. In positivist terms, Cunningham defended the primacy of the facts. For Cunningham (1887, p. 8) economics should be primarily an empirical science, concerned with description and classification:

Instead of aspiring to be a sort of Pure Physics of Society which assuming a single force - the individual desire for wealth - states the laws of the operation of this force in the supply and demand of different articles of value, Political Economy might for the present be content to observe and classify and describe and name as other sciences have been. ... No real advance can come from the statement of laws of phenomena which only hold good when a considerable number of cases are excluded as abnormal; if Political Economy is to rank with other empirical sciences one must try to classify the widely varied phenomena of industrial life ... as an empirical science in its classificatory stage.

Hence, according to the above statement, Cunningham's highly inadequate answer to the problem of historical specificity was that economists should be preoccupied with taxonomy. For Cunningham, the main role of 'theory' was to taxonomise categories for the purposes of empirical research. He objected to the assumptions of neoclassical economics in the following terms:

The underlying assumption against which I wish to protest is ... That the same motives have been at work in all ages, and have produced similar results, and that, therefore, it is possible to formulate economic laws which describe the action of economic causes at all times and in all places. (Cunningham, 1892b, p. 493) 
Cunningham (1892a, p. 12) also wrote at about the same time: 'We cannot then hope to find any strictly economic doctrine that gives us an adequate explanation of the phenomena of exchange in all times in all places'. Interestingly, Cunningham (1892b, p. 492) saw Spencer's work as an example of the dangers of excessive universality in theory. He dismissed Spencer thus: 'since he professes to know laws according to which all organisms develop, he need not trouble about the actual facts'. But this is a non sequitur. Knowledge of laws does not necessarily obviate the need for parametric and other data. Cunningham's remark was a sideways blow also against Marshall, who greatly admired Spencer.

It is true that Cunningham's insistence that economic theory had to have a strong, historically specific component illuminated Marshall's failure to develop one. However, Cunningham almost completely ruined his case by replacing this by a taxonomic empiricism, and by failing to recognise that even taxonomy requires some universal principles before it can proceed. Cunningham (1892a, p. 2) wrote: 'Economic doctrine about the actual world we live in is all built up as a branch of empirical knowledge; it has no universality.' Cunningham did not seem to realise that the negation of universality is itself a universal statement and that all empirical knowledge requires universal categories. Cunningham's extreme, untenable and self-contradictory empiricist position denied the very conceptual tools upon which all enquiry must proceed. Furthermore, Cunningham's criticisms of Marshall were so overstated and unconvincing that he became 'an outsider even among historical economists' such as Foxwell and William Ashley (Koot, 1987, p. 146).

Marshall (1892) responded to Cunningham. However, the Cunningham-Marshall debate did not go into great methodological depth. Marshall again conceded much of the historical school case: historical enquiry was essential for economic theory. Especially given this concession, Marshall's position was an attractive one, even for those young scholars who saw much of value in the work of the historical school. While valuing historical research, 
Marshall successfully argued that theoretical analysis was required to make sense of causal processes in history. In a clear reference to Cunningham, Marshall wrote to Foxwell on 27 March 1899 criticising those 'who are studying economic history as a mere series of facts' (Whitaker, 1996 vol. 2, p. 251).

A pale shadow of the Austro-German Methodenstreit, this British altercation over methods left Cunningham isolated and Marshall in a much stronger position. On the question of historical specificity, Marshall had conceded to the historical school, but from a philosophical standpoint that was stronger than that of his principal British adversary. Marshall chastised Cunningham for his naïve empiricism, not for his attention to the problem of historical specificity.

The Cunningham-Marshall controversy again came to the boil in the early 1900s. Although the controversy then involved the policy matter of free trade, the focal and decisive issue was the content of the economics curriculum in Cambridge. When the Economics Tripos was established in Cambridge in 1903, two full years of undergraduate study were devoted to economic theory, with only one year remaining for applied economics, economic history and politics. Cunningham protested. In 1905 the Economics Faculty Board posted a notice advising students that Dr. Cunningham, Director of Studies in Economics at Trinity College, 'has publicly declared himself to be out of sympathy with the study of economics under the direction of this Board'. Accordingly, students preparing for the examinations in economics were advised to seek council elsewhere (Koot, 1987, p. 149; Kadish, 1989, p. 218). This made Cunningham's permanent position at Cambridge unsustainable, and the following year he resigned his college fellowship. Cunningham's intransigent polarisation of the dispute encouraged a bureaucratic and doctrinal reaction, which led to outcomes opposite to those that he intended. 
Like many in the older (but not the younger) German historical school, Cunningham saw the salvation of theory in terms of empirical enquiry alone. He failed to understand Menger's forceful argument that even empiricism requires prior universal assumptions, such as the uniformity of nature. All empirical work requires prior universal concepts, such as units of measure. Taxonomies themselves require classificatory schema. All such concepts are tied up with explicit or implicit theories about the world. Theory is unavoidable, and has epistemic priority over facts. Cunningham did not understand this. Marshall did. It was tragic for the British historical school that some of its exponents fought on such weak methodological ground.

The historical school was not uniform in its methodology. Previous accounts of Marshall's relations with historical school have downplayed the difference between the historicists who developed theory (such as Gustav von Schmoller, Max Weber and Werner Sombart) and the more empiricist historicists (such as Wilhelm Roscher and William Cunningham). Marshall sympathised much more with Schmoller and his followers, although he went further than Schmoller in emphasising the analytical priority of theory.

The philosophical untenability of the empiricist position is not sufficiently emphasised in some modern accounts. Marshall was right to insist that empirical enquiry was impossible without theory, and that theory had priority. Like the astute historicists in Germany, Marshall had assimilated Menger's critique of empiricist historicism. So when he took dislike to some of the views of some of his historicist critics, it was their naïve empiricism rather than their historicism to which he primarily took exception. There is no major inconsistency between his public and his private persona here. Both his letters and his publications criticise empiricism, on the one hand, and praise the German historicist theorists, on the other. His tributes to the German historical school are repeated in his publications, up to and including the later editions of his Principles. ${ }^{[10]}$ 
Neither is it accurate to characterise Marshall's methodological views as simply 'eclectic' with Marshall 'prepared to use any method that produced helpful and useful results' (Moggridge, 1997, p. 365). On the contrary, Marshall's criticism of those who believed that theories could be spun from facts was relatively sophisticated for his time. Although Marshall's drive for a robust economic theory was eventually harnessed by his more formalistic neoclassical successors, the choice in 1885 was largely between historically informed theory, on the one hand, and naïve empiricism, on the other. Marshall adopted the stronger philosophical position. The tragedy is that Marshall failed to develop a theoretical framework within which the full sweep of historical development and structural change could be accommodated.

In the 1885-1908 period (from Marshall's inaugural lecture to his retirement) the general mood was one of Marshallian politeness and conciliation, rather than the disharmony of the Germanic Methodenstreit. Indeed, it is somewhat misleading to describe the Cambridge arguments of the period as a Methodenstreit at all. To repeat, unlike Menger, Marshall had explicitly recognised the problem of historical specificity. Regarding the contest between deductive and inductive methods - the second aspect of the Germanic Methodenstreit - a superficial but inadequate resolution had been reached when Marshall, like Schmoller, had accepted that both methods had to be combined: 'as the left foot and the right foot are both needed for walking.' Remarkably, these methodological discussions reached a high degree of consensus. The fact that a methodological dispute persisted at all was more to do with the relative intransigence of naïve empiricists like Cunningham, who never accepted a major role for economic theory. But the intransigent empiricists were never representative of either the German or the British historical schools in their totality. Compared with the clashes between Menger and Schmoller, the British Methodenstreit never reached the same degree of intensity 
or venom over methodological issues. In the British case, Methodendiskurs would be a better term.

Far from Marshall being an antagonist of historicism, it would be better to see Marshall as a representative and extension of the type of historically sensitive and theoretically informed thinking that had emerged in Germany by the end of the nineteenth century. To put it truthfully but provocatively, Marshall himself was a product and part of the historical school tradition.

It may be objected, however, that the net result of Marshall's particular efforts to assert the primacy of theory was to establish a neoclassical tradition that became progressively more formal, more technical, narrower and less historical. There is an element of truth here, but Marshall bears only part of the responsibility for the outcome. Crucially, despite his persistent recognition of the importance of the problem, Marshall never developed an adequate theoretical framework to deal with the issue of historical specificity. But other factors were beyond his control. In particular, the fragmented British historical school was much weaker than the German, and it lacked a sizeable cohort of methodologically and theoretically astute researchers.

Both such factors were in play when Marshall retired in 1908, and he did his best to ensure that the youthful Arthur Pigou got the job. Although Pigou was only 30 years of age at the time of the election of the chair, he had published much more extensively than Foxwell. To Foxwell’s chagrin and astonishment, Pigou's application was successful. ${ }^{[11]}$

Pigou subsequently developed formalistic aspects of Marshallian theory, addressing welfare economics and other matters. Whatever the merits and justification of Pigou's appointment to the chair, it is clear in retrospect that the elevation of this brilliant, but very young, theoretical economist marked the end of the period of Cambridge's intensive engagement with the German historical school. The huge generational leap from Marshall to 
Pigou meant the loss of much of the knowledge and awareness of historicism. If Pigou knew anything much about the German historical school, it is not apparent in his writing. Still a tiny department, with no more than two dozen undergraduate students (Groenewegen, 1995, p. 553), there were few to pass on an oral tradition of Marshallian connections with German historicism. Cambridge economics thus entered a period of relative intellectual isolation.

\section{A pluralistic academy}

Despite the historical caricatures of Robbins and others, the Marshallian period was one in which theorists and historicists worked alongside one another: there were differences of view but never a complete compartmentalisation, of viewpoints. For example, the young Ashley eventually to become a guiding light of the British historical school in the early twentieth century - was critical of aspects of Marshall's Principles but concluded with the following significant tribute and concordant evaluation:

The Principles of Economics is a work worthy of its author's reputation, and of his position as the doyen of English economists. ... It is the more welcome because it brings a message of conciliation to divergent schools, and it makes it possible for 'deductive' and 'historical,' 'scientific' and 'ethical' economists to work together in harmony. (Ashley, 1891, p. 489)

A similarly pluralistic spirit was evident when Edgeworth, the leading neoclassical economist and first editor of the Economic Journal, opened the first volume:

The Economic Journal ... will be open to writers of different schools. The most opposite doctrines may meet here as on a fair field. ... Nor will it be attempted to prescribe the method, any more than the result, of scientific investigation. (Edgeworth, 1891, p. 1) 
We find clear and plentiful evidence of the implementation of this pluralist policy in the early volumes of the Economic Journal. There are signs of the influence of historical school thinking on British economics, including challenges to the atomistic individualism of some economic theorists. In the theory of consumption, for instance, there were attempts to go beyond atomistic individualism and develop the theory of interdependent and socialised consumers. Henry Cunynghame (1892) discussed the interdependence of consumer demands, thus setting the limits of the independent individual. Caroline Foley (1893) went much further. Starting from a recognition of the historical specificity of socio-economic structures and behaviour, she saw the need to study consumption as a real, historically conditioned and socially structured process. Pigou $(1903,1913)$ subsequently made two attempts to incorporate interdependent and intersubjective aspects of consumer demand into neoclassical analysis. But Pigou (1913, p. 24) himself came to the conclusion that these attempts were 'wholly inadequate'. Not being readily formalised, these issues were eventually to slip off the agenda of mainstream economists in a later period (Mason, 1995; Fullbrook, 1998).

The failure of the British historicists was in part due to their own conception of scientific advance. None of the leading figures of the British school was able to build an alternative methodology or theory, and they remained largely entrapped by an empiricist epistemology. Largely for this reason, and despite the persistent influence of a few individuals, the historical school failed to establish an enduring bridgehead in the British Isles. Gradually pushed aside in academic argument, several members of the British historical school made their way into the discipline of economic history, embraced empiricism, and abandoned economic theory to the theorists. Crucially, the British historicists were overshadowed in the crucial encounters that occurred during the professionalisation of economics, and the establishment of distinct economics departments in several British universities in early part of the twentieth century. ${ }^{[12]}$ 
In justice, William Ashley and John A. Hobson were probably the two historicists sufficiently well qualified to succeed to Marshall's chair in 1908. Crucially for the fate of English economics, Ashley was away at the universities of Toronto and Harvard in the crucial years of from 1888 to 1900 . A graduate of Oxford, he returned to become Professor of Commerce at the University of Birmingham in 1901. Ashley disliked the drift towards 'pure theory' and argued for an economics based on history and business experience. His relatively sophisticated brand of historicism had explicit 'evolutionary' connotations, and he had an important influence on the important but fledgling subdiscipline of business economics (Ashley, 1907, 1924, 1926).

Hobson $(1902,1911,1914)$ openly embraced the metaphor of society-as-an-organism that was so central to German historicism. Fatefully, Hobson (1902) had criticised Marshall’s marginal utility theory. Although there are clear flaws in Hobson's argument, Marshall also did not come out of this debate without error (Maloney, 1985). Nevertheless, Marshall and his followers kept Hobson at arm's length. The influential American economist Richard Ely wrote to Marshall on 11 October 1901: 'I think that there is a feeling in this country that the English economists have not done justice to Hobson’ (Whitaker, vol. 2, p. 336). Indeed, Hobson has never received his due. He authored no less than 53 books and hundreds of articles, and influenced twentieth century thinkers as important as Lenin and J. M. Keynes. Yet he was denied any university post. He died in 1940 as the last - and most long-lived - of the British historicists. His death marked the end of a tradition that failed to establish an enduring foothold and identity in British universities. This did not mean, however, that it did not make a mark. In a qualified by significant sense, one of its most important representatives of British historicism was Marshall himself.

\section{References}


Ashley, William J. (1891), The Rehabilitation of Ricardo', Economic Journal, 1(3), September, pp. 474-89.

Ashley, William J. (1907), ‘The Present Position of Political Economy’, Economic Journal, 17(4), December, pp. 467-89.

Ashley, William J. (1924), 'Evolutionary Economics', in Birkbeck College Centenary Lectures: 1823-1923. A Course of Lectures Given at the College in Connection With the Celebration of the Centenary, with a Preface by J. Ramsay McDonald MP (London: University of London Press), pp. 35-61.

Ashley, William J. (1926), Business Economics (London: Longmans, Green).

Black, R. D. C., Coats, A. W. and Goodwin, Craufurd D. (eds) (1973) The Marginal Revolution in Economics (Durham: Duke University Press).

Coase, Ronald H. (1972), 'The Appointment of Pigou as Marshall's Successor', Journal of Law and Economics, 15, October, pp. 473-85.

Coats, A. W. (1968) 'Political Economy and the Tariff Reform Campaign of 1903', Journal of Law and Economics, 11, April, pp. 181-229.

Coats, A. W. (1972), 'The Appointment of Pigou as Marshall's Successor: Comment', Journal of Law and Economics, 15, October, pp. 487-95.

Cunningham, William (1885), Politics and Economics: An Essay on the Nature of the Principles of Political Economy, Together with a Survey of Recent Legislation (London).

Cunningham, William (1887), Political Economy Treated as an Empirical Science: A Syllabus of Lectures (Cambridge).

Cunningham, William (1892a), 'The Relativity of Economic Doctrines’, Economic Journal, 2(1), March, pp. 1-16. 
Cunningham, William (1892b), ‘The Perversion of Economic History’, Economic Journal, 2(3), September, pp. 491-506.

Cunynghame, Henry (1892), 'Some Improvements in Simple Geometrical Methods of Treating Exchange Value, Monopoly and Rent', Economic Journal, 2(1), March, pp. $35-52$.

Edgeworth, Francis Y. (1891), 'The British Economic Association', Economic Journal, 1(1), March, pp. 1-2.

Ekelund, Robert B. Jr. and Hébert, Robert F. (2002) 'The Origins of Neoclassical Economics', Journal of Economic Perspectives, 16(3), Summer, pp. 197-215.

Foley, Caroline A. (1893), 'Fashion’, Economic Journal, 3(3), September, pp. 458-74.

Foxwell, Herbert S. (1919), ‘Archdeacon Cunningham’, Economic Journal, 29(3), September, pp. 382-95.

Fullbrook, Edward (1998), 'Caroline Foley and the Theory of Intersubjective Demand', Journal of Economic Issues, 32(3), September, pp. 709-731.

Groenewegen, Peter (1995), A Soaring Eagle: Alfred Marshall 1842-1924 (Aldershot: Edward Elgar).

Hammond, J. Daniel (1991), ‘Alfred Marshall’s Methodology’, Methodus, 3(1), June, pp. 95101.

Hobson, John A. (1902), The Social Problem: Life and Work (London: James Nisbet).

Hobson, John A. (1911), The Science of Wealth (London: Williams and Norgate).

Hobson, John A. (1914), Work and Wealth: A Human Valuation (London: Macmillan).

Hodgson, Geoffrey M. (1993), Economics and Evolution: Bringing Life Back Into Economics (Cambridge, UK and Ann Arbor, MI: Polity Press and University of Michigan Press).

Hodgson, Geoffrey M. (2001), How Economics Forgot History: The Problem of Historical Specificity in Social Science (London and New York: Routledge). 
Howey, Ralph S. (1960), The Rise of the Marginal Utility School (Lawrence, KA: University of Kansas Press).

Hutchison, Terence W. (1988), 'Gustav Schmoller and the Problems of Today', Journal of Institutional and Theoretical Economics, 144(3), pp. 527-531.

Hutchison, Terence W. (1998), 'Ultra-Deductivism from Nassau Senior to Lionel Robbins and Daniel Hausman’, Journal of Economic Methodology, 5(1), June, pp. 43-91.

Jones, Trevor W. (1978), 'The Appointment of Pigou as Marshall’s Successor: The Other Side of the Coin', Journal of Law and Economics, 21, April, pp. 234-43.

Kadish, Alon (1989), Historians, Economists and Economic History (London: Routledge).

Kadish, Alon and Tribe, Keith (eds) (1993), The Market for Political Economy: The Advent of Economics in British University Culture, 1850-1905 (London: Routledge).

Kant, Immanuel (1929), Critique of Pure Reason, translated from the second German edition of 1787 with an introduction by Norman Kemp Smith (London: Macmillan).

Keynes, John Maynard (1972), The Collected Writings of John Maynard Keynes, Vol. X, Essays in Biography (London: Macmillan).

Keynes, John Neville (1891), The Scope and Method of Political Economy (London: Macmillan).

Koot, Gerard M. (1987), English Historical Economics 1870-1926: The Rise of Economic History and Neomercantilism (Cambridge: Cambridge University Press).

Maloney, John (1985), Marshall, Orthodoxy and the Professionalisation of Economics (Cambridge: Cambridge University Press).

Marshall, Alfred (1885), 'The Present Position of Economics', in Arthur C. Pigou (ed.) (1925) Memorials of Alfred Marshall (London: Macmillan), pp. 152-74.

Marshall, Alfred (1890), Principles of Economics: An Introductory Volume, 1st edn. (London: Macmillan). 
Marshall, Alfred (1892), 'A Reply to “The Perversion of Economic History” by Dr. Cunningham’, Economic Journal, 2, pp. 507-19.

Marshall, Alfred (1919), Industry and Trade (London: Macmillan).

Marshall, Alfred (1949), The Principles of Economics, 8th (reset) edn. (1st edn. 1890) (London: Macmillan).

Marshall, Alfred and Marshall, Mary Paley (1881), Economics of Industry, 2nd edn. (London: Macmillan).

Mason, Roger S. (1995), 'Interpersonal Effects on Consumer Demand in Economic Theory and Marketing Thought, 1890-1950', Journal of Economic Issues, 29(3), September, pp. 871-81.

Moggridge, Donald E. (1997), 'Method and Marshall', in Koslowski, Peter (ed.) (1997) Methodology of the Social Sciences, Ethics, and Economics in the Newer Historical School: From Max Weber and Rickert to Sombart and Rothacker (Berlin: Springer), pp. 342-69.

Pigou, Arthur C. (1903), ‘Some Remarks on Utility’, Economic Journal, 13(1), March, pp. 58-68.

Pigou, Arthur C. (1913), 'The Interdependence of Different Sources of Demand and Supply in a Market’, Economic Journal, 23(1), March, pp. 19-24.

Pigou, Arthur C. (ed.) (1925) Memorials of Alfred Marshall (London: Macmillan).

Pribram, Karl H. (1983), A History of Economic Reasoning (Baltimore, MD: Johns Hopkins University Press).

Robbins, Lionel (1998), A History of Economic Thought: The LSE Lectures, edited by Steven G. Medema and Warren J. Samuels (Princeton, NJ: Princeton University Press).

Seager, H. R. (1893), 'Economics at Berlin and Vienna', Journal of Political Economy, 1(2), pp. 236-62. 
Shove, Gerald F. (1942), 'The Place of Marshall's Principles in the Development of Economic Theory’, Economic Journal, 52(4), December, pp. 294-329.

Skidelsky, Robert (1983), John Maynard Keynes: Volume One: Hopes Betrayed, 1883-1920 (London: Macmillan).

Thomas, Brinley (1991), 'Alfred Marshall on Economic Biology', Review of Political Economy, 3(1), January, pp. 1-14.

Whitaker, John K. (ed.) (1996), The Correspondence of Alfred Marshall, 3 vols (Cambridge: Cambridge University Press).

\section{Notes}

${ }^{[1]}$ This essay draws extensively from Hodgson (2001, ch. 8).

${ }^{[2]}$ On Marshall’s complex and enigmatic character see Groenewegen (1995, ch. 21) and T. W. Jones (1978).

${ }^{[3]}$ Nevertheless, of course, the methodological and theoretical issues were linked in the discussion. See Seager (1893) for an early account of the context and content of the controversy.

${ }^{[4]}$ See the several positive references to Knies, List, Roscher, Schäffle, Schmoller, Wagner and other German historicists that are indexed in Marshall $(1919,1949)$, and in Marshall and Marshall (1881).

${ }^{\text {[5] }}$ At the time, Seager (1893, p. 237) quoted Marshall’s conciliatory and eclectic methodological statements in his Principles, and concluded that: 'What Professor Marshall says in regard to method may be quoted as a very fair summary of contemporary German opinion.' Along broadly similar lines, Shove (1942, p. 309) later remarked: 'If any school of thought outside the Ricardian tradition set its mark on the Principles it was the Historical School, rather than the marginal utility school, that did so.' One of the few post-1945 commentators to likewise emphasise Marshall's methodological continuity with the German historical school was Hutchison (1988, p. 529) who wrote: 'Alfred Marshall, under German influence, made a strenuous attempt to re-graft a historical-institutional approach on to the neo-classical abstraction.'

${ }^{[6]}$ A problem with Schmoller's statement, however, is that a mixture of two philosophically unsatisfactory methods - induction and deduction - is unlikely to produce a satisfactory result. The intention here is to show the endorsement of Schmoller by Marshall, rather than to sanction Schmoller's methodological formulation. 
${ }^{[7]}$ The historical school of the British Isles is often mistakenly described as the 'English' historical school.

However, its earliest leaders, such as Leslie and Ingram, were born and taught in Ireland. Cunningham, who was Marshall's antagonist in Cambridge, was born in Scotland.

${ }^{[8]}$ Notably, in his successful application for the Tooke Chair, Cunningham secured a positive reference from Marshall (Whitaker, 1996, vol. 2, p. 33).

${ }^{[9]}$ This is an extract from Foxwell's unsuccessful 1901 application to the chair of commerce at the University of Birmingham, to which Ashley was in fact appointed (quoted in J. M. Keynes, 1972, p. 270).

${ }^{[10]}$ In general, Marshall dealt with his antagonists with civility. Perhaps Marshall's most hostile statement against the empiricist historians was in his letter to J. N. Keynes of 27 May 1889 where he wrote: 'I want however to keep my hold on the Historical men: they are Kittle-Kattle, and yet important' (Whitaker, 1996, vol. 1, p. 290). Yet this statement has an unclear meaning. It does not imply that Marshall was hostile to the historical school as a whole. The phrase 'Kittle-Kattle' could be a reference to the 'Chit Chat Club'. This was a select and exclusive academic circle within the University of Cambridge, limited to 15 members. Cunningham, Foxwell and J. N. Keynes were members but strangely Marshall was never invited to join (Groenewegen, 1995, pp. 110, 444).

${ }^{[11]}$ Cannan and Ashley were the other two candidates for Marshall's chair. For discussions of the reasons and processes behind Foxwell's rejection and Pigou's appointment see Coase (1972), Coats (1968, 1972), T. W. Jones (1978) and Groenewegen (1995, pp. 622-7). Coase (1972) points out that in 1900-1908, Pigou published no less than ten articles in the Economic Journal and five books. In contrast, in the same period, Foxwell published no books and just one substantial article - in the Palgrave Dictionary of Political Economy. On the other hand, Foxwell's service to the university was much the greater. Marshall's correspondence reveals his criticisms of Foxwell. In a letter to Foxwell of 12 February 1906, Marshall politely and honestly noted their personal differences in 'ideals in economics' and of academic judgment. The most revealing letter is to J. N. Keynes, dated 13 December 1908. Here Marshall criticised Foxwell as a lecturer who 'imposes his judgment on youth' rather than trying 'to develop faculty, and to leave judgment to be formed later'. Marshall also wrote: 'Foxwell's judgments, while always confident, are likely to be in opposite directions at six months notice, I have fear of his judgments. ... He seems never to see more than one side of any complex question' (Whitaker, 1996, vol. 3, pp. 126, 215). Notably, Groenewegen (1995, p. 625) argued convincingly that Marshall did not abandon support for Foxwell and support Pigou as is future successor until 1906. In supporting Pigou, Marshall had acted on his academic judgment, but it caused an irreparable breach with his closest friend. 
${ }^{[12]}$ See Kadish (1989), Kadish and Tribe (1993), Koot (1987) and Maloney (1985). However, the growth of economics in Britain as a separate discipline under the leadership of Marshall and his followers, and its separation from economic history, did not amount to a 'disintegration of political economy' as some have suggested. In truth, neither Marshall nor his predecessors had an adequately integrated system of political economy. If there was any 'integration’ before (say) 1900 it was more to do with the fact that these subjects were often taught together, rather than the existence of any guiding overall framework or discipline of 'political economy'. Furthermore, the story concerning the relationship between economics and economic history is very different in Germany and the USA, and we cannot generalise from the British experience 